\section{Biblica}

et

Patristica

Thoruniensia

10 (2017) 2: 287-289

ISSN (print) 1689-5150

ISSN (online) 2450-7059

\title{
Recenzja książki: N. O'Hear, A. O'Hear, Picturing the Apocalypse. The Book of Revelation in the Arts Over Two Millennia, Oxford University Press, Oxford 2015, s. LIV + 333, ISBN 978-0-19-968901-9.
}

Słowa kluczowe: Apokalipsa; historia recepcji; egzegeza; sztuka.

Keywords: Revelation; history of reception; exegesis; art.

$\mathrm{K}$ siążka Picturing the Apocalypse jest dziełem interdyscyplinarnym, łączącym w sobie elementy egzegezy, historii recepcji i historii sztuki. Jest jedyną wspólną pracą autorów. Anthony O’Hear jest profesorem filozofii w The University of Buckingham, natomiast Natasha O’Hear doktorem oraz wykładowcą teologii i sztuk wizualnych w The Institute of Theology, Imagination and the Arts w St Andrews. Ta druga jest autorką publikacji zatytułowanej Contrasting Images of the Book of Revelation in Late Medieval and Early Modern Art (Oxford University Press, 2011), dla której recenzowane dzieło ma stanowić kontynuację i rozwinięcie.

Książka składa się z obszernego wstępu, dziesięciu rozdziałów oraz zakończenia. Zawiera także liczne przedstawienia omawianych dzieł sztuki. Część $\mathrm{z}$ nich umieszczona jest $\mathrm{w}$ tekście, a pozostała część znajduje się na początku książki.

Wstęp w dość precyzyjny sposób wprowadza czytelnika w opisywaną tematykę oraz w wybraną metodologię. Autorzy postawili sobie za cel, aby przedstawić, w jaki sposób Apokalipsa była interpretowana na przestrzeni wieków. Jednak nie chodzi tutaj o naukowe analizy, lecz przekaz artystyczny. Gobeliny, freski, ilustracje do manuskryptów, obrazy ołtarzowe oraz witraże mają wyrażać rozumienie treści Objawienia. Dzieła sztuki mogą służyć jako forma interpretacji Biblii. Po określeniu tła historycznego Apokalipsy zostaje wyłonione dziewięć motywów będących najczęstszą inspiracją dla artystów oraz najbardziej obecnych we współczesnej kulturze (także popularnej). 
Następne dziewięć rozdziałów opisuje następujące tematy: aniołów, Baranka, Czterech Jeźdźców, siedem pieczęci (oraz trąb i czar), Niewiastę obleczoną w Słońce, szatańską „trójcę”, Wielką Nierządnicę, Armagedon i sąd ostateczny, Nowe Jeruzalem. Każdy z nich ma podobną do siebie strukturę. Zawsze na początku rozdziału autorzy starają się przybliżyć czytelnikowi omawiany motyw, opatrując go komentarzem teologicznym i historycznym. Następnie można znaleźć omówienie szeregu przedstawień artystycznych dotyczących danego tematu oraz zwięzłe podsumowanie danego rozdziału, płynnie wprowadzające do następnej tematyki. Omawiane dzieła sztuki prezentowane są na ogół w kolejności chronologicznej. Ilustracje omawiane w jednym miejscu osadzone są w tekście, dla wygody czytelnika. Natomiast te, do których odwołania są czynione $\mathrm{w}$ wielu miejscach, zostały umieszczone na początku książki. Autorzy starają się nie tylko dokładnie opisać, co zostało przedstawione w poszczególnych dziełach sztuki, lecz także dokonują analizy teologicznej.

Autorzy zwracają uwagę na kilka znaczących sposobów podejścia do tekstu Apokalipsy. Artyści przedstawiają księgę z perspektywy diachronicznej, tworząc szereg dzieł zawierających kolejne motywy i treści z poszczególnych rozdziałów Ap, lub w sposób synchroniczny, pokazując wiele wydarzeń w jednym ujęciu. Treść może też być ujęta literalnie bądź metaforycznie. Każdy rozdział zawiera zestawienie tych różnych interpretacji artystycznych.

Rozdział 10 różni się nieco od pozostałych. Pokazuje nawiązania do różnych motywów apokaliptycznych w kulturze i sztuce współczesnej (wysokiej i popularnej). Inna jest też struktura rozdziału. Najpierw omówione zostają sztuki wizualne, następnie muzyka klasyczna, muzyka rozrywkowa, film, literatura, a także znaczenie Apokalipsy w kulturze afrykańskiej i latynoamerykańskiej. Autorzy zwracają uwagę na zeświecczenie symboli i motywów Biblijnych. Według nich, zniekształceniu uległo wiele pojęć takich jak sama „Apokalipsa” czy „Armagedon”, które współcześnie rozumiane są jako synonimy końca świata i towarzyszących temu destrukcyjnych wydarzeń. Natomiast w kręgach latynoamerykańskich i afrykańskich komentatorów biblijnych, księga staje się często podstawą do uprawiania różnorakiej teologii wyzwolenia.

Zakończenie jest podsumowaniem całości książki. Można też tam znaleźć rozważanie nad znaczeniem Księgi Apokalipsy we współczesnej kulturze. Godnym uwagi jest stwierdzenie, że Ap nie proponuje nowego porządku świata, lecz skłania do transformacji moralnej człowieka i krytycznej oceny wyznawanych dziś wartości.

Książka zawiera w sobie swoistą narrację, która w płynny sposób prowadzi czytelnika z jednego punktu do drugiego, co sprawia, że jest łatwa w odbiorze. Nawet niezaznajomieni z tekstem Apokalipsy mogą z łatwością zrozumieć omawiane treści. Słabością jest umieszczenie przypisów na samym końcu 
książki, a na dodatek dla każdego rozdziału stosowana jest osobna numeracja. Jakkolwiek jest to uczynione konsekwentnie, stwarza to pewne trudności w odszukiwaniu odnośników. W rozdziale 9 można natrafić na rażący błąd merytoryczny. Autorzy poprawnie i zgodnie z tradycyjnymi komentarzami rozpoznają paralelę między drzewem z Ap 22,2 oraz drzewem życia z Rdz 2,9. Jednak błędnie dokonują utożsamienia tego drugiego z drzewem poznania dobra i zła (również $\mathrm{Rdz}$ 2,9). Trudno stwierdzić, z czego może wynikać takie niedopatrzenie, gdyż ustęp nie jest opatrzony żadnym przypisem. Nie zmienia to jednak całościowego i wyczerpującego ujęcia omawianego tematu. Cel określony we wstępie można uznać za w całości zrealizowany. Niezwykle interesującym jest pokazanie, jak wielką skuteczność egzegetyczną może mieć obraz. Autorzy sięgają do bardzo bogatego zasobu przedstawień artystycznych. Dzięki temu książka może posłużyć jako odniesienie dla historyków sztuki. Odnaleźć można też refleksję teologiczną, która skutecznie umożliwia pogłębienie zrozumienia Apokalipsy. Ukazanie, jak wielkie znaczenie ma ta księga, nawet w dzisiejszej zsekularyzowanej kulturze, stanowi zachętę do rozszerzonych badań nad jej treścią i znajdowania wniosków dla życia osobistego.

Książka Picturing the Apocalypse stanowi unikalne połączenie historii recepcji, historii sztuki i teologii. Możliwe, że jest to skuteczny sposób przybliżenia nieraz bardzo skomplikowanych treści w przystępnej formie. Przydatne wiadomości mogą w niej znaleźć zarówno bibliści, historycy i znawcy sztuki, jak i laicy zainteresowani tematyką.

\section{Bibliografia}

O'Hear N., O'Hear A., Picturing the Apocalypse. The Book of Revelation in the Arts Over Two Millennia, Oxford University Press, Oxford 2015, ss. LIV + 333.

O'Hear N., Contrasting Images of the Book of Revelation in Late Medieval and Early Modern Art: A Case Study in Visual Exegesis, Oxforf University Press, Oxford 2011, ss. 287.

Wood S.J., The Alter-Imperial Paradigm. Empire Studies \& the Book of Revelation, Brill, Leiden - Boston 2016, ss. XIV + 300.

Jelonek T., Biblia $w$ kulturze świata, Kraków 2007, ss. 258.

Bazyliński S., Wprowadzenie do studium Pisma Świętego, Lublin 2010, ss. 238. 